\section{Development of In-ground Container Plants of Mexican Elders Exposed to Drought}

Cathleen Feser $^{1}$ and Rolston St. Hilaire ${ }^{2}$

Department of Agronomy and Horticulture, New Mexico State University, Box 30003, Las Cruces, NM 88003

\section{Dawn VanLeeuwen \\ Agricultural Biometric Service, New Mexico State University, Box 30003, Las Cruces, NM 88003}

Additional index words. net assimilation rate, relative growth rate, relative water content,

Sambucus mexicana

\begin{abstract}
Mexican elder (Sambucus mexicana Presl.) is used in arid landscapes of the Southwest, but the plant is known for its unpredictable performance in those landscapes. We studied drought responses of mexican elder plants grown in an arid environment using an in-ground nursery production system. Plants were maintained as well-irrigated controls or exposed to cyclic drought and irrigated based on evapotranspiration. Drought treatment lasted 165 days. Plants exposed to drought had more negative predawn and midday water potentials than well-watered plants. The ratio of variable to maximal fluorescence $\left(F_{v} / F_{m}\right)$ for the drought group $(0.76)$, was near the optimum value of 0.8 , suggesting that chloroplasts of drought-stressed plants maintained high levels of activity. Drought cycle, but not drought treatment affected stomatal conductance. Drought-stressed plants had lower transpiration rates than controls except at drought cycle five when transpiration rates were similar between irrigation treatments. Relative water content was higher in controls $(76 \%)$ than plants exposed to drought $(66 \%)$. Leaf area of well-irrigated plants was over four times higher than that of plants exposed to drought. Leaf area to root dry weight ratio of drought-stressed plants was $79 \%$ lower than control plants. Severely reduced leaf area of drought-stressed plants might be one reason why landscape personnel conclude that mexican elder plants perform poorly in arid landscapes.
\end{abstract}

Mexican elder(Sambucus mexicana Presl.) is a woody landscape plant that is planted in managed landscapes of the Southwest (St. Hilaire et al., 2003), but reasons for the unpredictable performance of the plant remain largely unresolved. Empirical observations have causally linked reduced leaf size and leaf abscission in mexican elder to water-limited conditions (Feser, 2003), but scientific information about drought responses of the plant is virtually nonexistent.

Typically, woody landscape plant responses to drought are assessed with production systems that use in-field plants and conventional aboveground container plants. These production systems either limit the type of experimental data that can be tracked or do not accurately reflect the actual landscape environment of the plant. For example, in-field plants can not be weighed to determine moisture loss without compromising plant growth. Also, roots and

Received for publication 18 Apr. 2004. Accepted for publication 23 Sept. 2004. Contribution of the N.M. Agricultural Experiment Station, N.M. State Univ., Las Cruces. This work was supported in part with federal funds through USDA-CSREES under agreement numbers 2001-34461-10405 and 2001-45049-01149 to New Mexico and Texas for Experiment Station research and extension educational programs.

${ }^{1}$ Current address: Univ. Florida/IFAS, Collier County

Extension, Naples, FL 34120.

${ }^{2}$ Corresponding author; e-mail rsthilai@nmsu.edu. shoots of plants in an above-ground container system are exposed to an above-ground environment.

However, in the in-ground container system, a plant's roots are sunken below ground while only the shoots are exposed to aboveground conditions. The entire plant can be weighed to determine gravimetric moisture loss (St. Hilaire et al., 2003). Compared to the above-ground nursery production system, the in-ground container system contributes to reduced plant stress by modifying root and soil temperatures and stabilizing soil moisture content(Martin et al., 1999; Ruter, 1998; Young and Bachman, 1996). Thus, the in-ground nursery production system combines some of the advantages of the in-field and above-ground nursery production system.

We developed a system to obtain accurate gravimetric data for large mexican elder plants grown in an in-ground container nursery production system (St. Hilaire et al., 2003). The in-ground container (pot-in-pot) system is well established in the nursery industry (Adrian etal., 1998; Martin etal., 1999; Ruter, 1998).Although the in-ground container system has been used to determine water use (Devitt et al., 1995; Martin et al., 1999; Ruter, 1998), few researchers have tested drought responses of woody plants using in-ground container systems. The objective of this study was to identify drought responses of mexican elder using an in-ground nursery production container system.
Field conditions and plant materials. The experiment was conducted in an open field located at New Mexico State University's Fabian Garcia Science Center in Las Cruces (elevation $1183 \mathrm{~m}$, lat. $32^{\circ} 16^{\prime} 4^{\prime \prime} \mathrm{N}$, long. $106^{\circ} 46^{\prime} 18^{\prime \prime} \mathrm{W}$ ). An in-ground container nursery production system was installed in the field as described by St. Hilaire et al. (2003). The surface among pots was bare native soil (Glendale clay). Pots were spaced $2.9 \mathrm{~m}$ within rows and $3.66 \mathrm{~m}$ between rows.

On 2 Oct. 2000, 13 three-year-old mexican elder plants in 57-L plastic pots were obtained from Sunland Nursery (Las Cruces). Plants were first kept in a greenhouse until Nov. 3, 2000 (5 weeks). From 4 Nov., plants were moved to an open-sided lathe house $(26 \%$ shade) and kept there until 12 Apr. 2001 (23 weeks). Plants were watered as needed. Daily midday temperature and relative humidity in the greenhouse averaged $23 \pm 1{ }^{\circ} \mathrm{C}$ and $88 \% \pm$ $5 \%$ respectively. Average midday temperature, relative humidity, and PPFD in the lathe house were $19.6 \pm 4.8{ }^{\circ} \mathrm{C}, 27 \% \pm 8 \%$, and $1350 \pm$ $548 \mu \mathrm{mol} \cdot \mathrm{m}^{-2} \cdot \mathrm{s}^{-1}$, respectively.

On 13 Apr. 2001, plants were removed from their original containers and repotted into the 76-L (20-gal) plastic holder pots (top inside diameter $=48.3 \mathrm{~cm}$; height $=43.2 \mathrm{~cm})($ Classic 8000 Econo-Grip; Nursery Supplies, Orange Calif.) of the in-ground container system. We used relatively large pots to limit the impact of pot volume on root growth. Average tree height was $93 \pm 32 \mathrm{~cm}$, and stem diameter 15 $\mathrm{cm}$ above the substrate surface averaged 3.6 $\pm 1 \mathrm{~cm}$. The growing substrate in the holder pot consisted of four hyponex pine bark mulch (Hyponex Corp., Marysville, Ohio) and one washed sand (Certified Sand, Las Cruces, N.M.) (by volume), amended with slow release fertilizer(Osmocote, 15N-22P-13.2K, Scotts, Marysville, Ohio) at a rate of $2.33 \mathrm{~kg} \cdot \mathrm{m}^{-3}$. Air-filled porosity of the substrate was $26 \%$ and water content was $35 \%$ as determined by procedures outlined by Handreck and Black (2002).

On 16 Apr. 2001, trees were transported to the field site $(200 \mathrm{~m})$ and inserted into the socket pots of the in-ground container system. Plants remained in the field until irrigation treatments were initiated.

Initial harvest and experimental design. On 18 Feb. 2002, irrigation treatments were initiated. Three plants were randomly selected and destructively harvested. Leaf surface area was measured with a leafarea meter (LI3000A; LI-COR, Lincoln, Nebr.). Stems of all plants were severed $2 \mathrm{~cm}$ above the growing substrate. Roots were washed free of growing substrate using water. Leaves, stems, and roots were oven dried for $14 \mathrm{~d}$ at $65^{\circ} \mathrm{C}$. The experimental design was a completely randomized design, with two irrigation treatments (control and drought) and five single plant replications in each treatment.

Irrigation treatment. Control plants were irrigated daily with $3 \mathrm{~L}$ of tap water and plants in the drought treatment were irrigated in cycles. Leaching fraction from pots averaged 
15\%. Evapotranspiration (ET) of individual pots was monitored gravimetrically. Adrought cycle ended when the average weight of the five pots decreased approximately $30 \%$ due to ET. To determine whether pot weight decreased by $30 \%$, we weighed all plants weekly after the start of a drought cycle. In addition, plants in the drought treatment were weighed every other day or daily as the end of a drought cycle approached. Our preliminary observations of three plants of mexican elder revealed that a drought level of $30 \%$ ET was severe enough to cause severe wilting but not mortality. Plants were subjected to five drought cycles ranging from 12 to $28 \mathrm{~d}$ (Table 1). After measurements were taken at the end of each drought cycle, plants were irrigated daily for a $14 \mathrm{~d}$ recovery period. Control plants were fertilized weekly with $100 \mathrm{mg} \cdot \mathrm{L}^{-1}$ of nitrogen made from Peters Excel (15N-2.2P-12.5K) (Scots, Marysville, Ohio). Drought-stressed plants were fertilized at the end of the drought cycle, and then weekly during the recovery period. Drought-stressed plants were fertilized with the same solution as the control plants. To determine initial pot weight at the start of a drought cycle, each plant was irrigated at $0600 \mathrm{HR}$, allowed to drain for $2 \mathrm{~h}$, and weighed at $0800 \mathrm{HR}$ (St. Hilaire, 2003). Irrigation was then withheld from plants in the drought treatment until the combined weight had decreased by $30 \%$ due to evapotranspiration. At $30 \%$ gravimetric moisture loss, volumetric moisture content of the upper $6 \mathrm{~cm}$ of the substrate surface was 0.026 $\pm 0.006 \mathrm{~m}^{3} \cdot \mathrm{m}^{-3}$. Volumetric moisture content was determined with a theta probe (type HH1; Delta-T Devices, Cambridge, U.K.) set on the organic option. Pots were lifted with a block and tackle system (St. Hilaire et al., 2003), and weighed with a top-loading balance (model QC 60FEG-SOUR; Sartorius Corp., Edgewood, N.Y.), accurate to $1 \mathrm{~g}$ at its maximum load capacity of $60 \mathrm{~kg}$.

Plant water relations. On the day a drought cycle ended, irrigation also was withheld from controls. The next day, predawn (0500 HR) stem water potential was measured with a pressure chamber (model 1000; PMS Instruments, Corvallis, Ore.). Twigs in the top third of the plant crown containing young, fully expanded leaves were selected for predawn measurements and twigs opposite those selected for predawn measurement were used for midday measurements. Predawn $\left(\psi_{\mathrm{pd}}\right)$ and midday $\left(\psi_{\mathrm{md}}\right)$ stem water potential data were collected at the end of drought cycles three, four, and five.

Atmidday (1200 to $1300 \mathrm{HR}$ ), measurements of stem water potential, transpiration, stomatal conductance, chlorophyll fluorescence and cell osmolality were initiated. Transpiration and stomatal conductance were measured with a steady-state porometer (LI-1600; LI-COR) on the terminal leaflet of the youngest fully expanded leaf of the twig selected for midday water potential.

Chlorophyll fluorescence. Chlorophyll fluorescence measurements were taken on leaves that were dark-adapted for $30 \mathrm{~min}$. The youngest fully expanded terminal leaflet on the twig opposite to the one selected for porometry measurement was selected for fluorescence measurements. Measurements were recorded using a continuous source fluorometer (OS-30; Opti-Sciences, Tyngsboro, Mass.). Excitation source intensity for the fluorometer was set at $3000 \mu \mathrm{mol} \cdot \mathrm{m}^{-2} \cdot \mathrm{s}^{-1}$.

Cell osmolality. For cell osmolality measurements, the leaf previously selected for porometry measurement was excised, sealed in a ziplock plastic bag, placed on ice in a cooler, and immediately transported (about $1.5 \mathrm{~km}$ ) to the laboratory. Leaves were rolled, placed into a Markhart leaf press (model LP-27; Wescor, Logan, Utah), and pressed to transfer cell contents onto paper discs (SS033 sample discs, Wescor). Discs were then placed into a self-calibrating vapor pressure osmometer (Vapro model 5520; Wescor) to determine cell osmolality. Values for cell osmolality $\left(\mathrm{mmol} \cdot \mathrm{kg}^{-1}\right)$ were converted to cell osmotic potential (-MPa) using van't Hoff's equation.

Relative water content. At midday on 2 Aug. 2002, a youngest fully expanded leaf from a twig on the terminal portion of each plant was excised, sealed in a ziplock plastic bag, placed on ice in a cooler, and immediately transported to our laboratory (about $1.5 \mathrm{~km}$ ). Two leaf discs $\left(49 \mathrm{~mm}^{2}\right)$ were removed from the interveinal region of the leaves with a cork borer. Discs were then weighed to determine fresh weight (FW). Preliminary experiments revealed that discs were fully turgid after four hours of rehydration. So, after four hours of rehydration in deionized water, discs were blotted with lintless paper to remove excess moisture and re-weighed to obtain turgid weight (TW). Discs were then dried in an oven for $10 \mathrm{~h}$ at $85^{\circ} \mathrm{C}$. Dry weight (DW) was recorded, and relative water content (RWC) was determined using the formula RWC (\%) $=(\mathrm{FW}-\mathrm{DW}) /(\mathrm{TW}-\mathrm{DW}) \times 100$.

Final destructive harvest. On 2 Aug. 2002, the experiment ended after $165 \mathrm{~d}$. Predawn and midday water potential measurements were taken as described previously. Leaf area of all plants was measured with the LI 3000A leaf area meter. Stems of all plants were severed 2 $\mathrm{cm}$ above the growing substrate surface. Leaves and stems were oven dried for $14 \mathrm{~d}$ at $65^{\circ} \mathrm{C}$. Specific leaf weight (SLW) was calculated as leaf DW divided by leaf area. Roots were water-washed free of growing substrate. To separate fine roots from the growing substrate, all growing substrate was sifted through a series of five sieves (12, 6, 4, 2, and $1 \mathrm{~mm}$ ) until all roots had been retrieved. Root balls and fine roots were oven-dried at $65^{\circ} \mathrm{C}$ for $14 \mathrm{~d}$ and 7 d, respectively.

Statistical analyses. All data were analyzed using SAS (SAS Inst., Cary, N.C.). Significance was defined at $P \leq 0.05$. Proc Mixed procedure of SAS was used to assess treatment effects, drought cycle effects, and treatment by drought cycle interactions using a mixed model that accounted for trees and drought cycles within trees and tree height as a covariate factor. A basic split-plot type of analysis with trees within treatment serving as whole plots and drought cycles within trees as the split-plot was selected as the best covariance structure through time for the variables of predawn water potential, minimal fluorescence $\left(\mathrm{F}_{\mathrm{o}}\right)$, maximal fluorescence $\left(\mathrm{F}_{\mathrm{m}}\right)$, and osmolality. For $\mathrm{F}_{\mathrm{v}} / \mathrm{F}_{\mathrm{m}}$ and transpiration, a model that incorporated unstructured covariance through drought cycles was selected, while midday water potential was analyzed using a model incorporating the $\mathrm{sp}$ (pow) covariance structure. The model for stomatal conductance estimated compound symmetric covariance structures separately for each of the two treatment groups. For $\mathrm{F}_{\mathrm{v}} / \mathrm{F}_{\mathrm{m}}$, transpiration, midday water potential and stomatal conductance, the Kenward-Rogers (KR) option was used to adjust denominator degrees of freedom and error estimates. Contrasts and model-based $t$ tests (LSDs) comparing least squares means were used to explore the nature of significant effects. The two-independent samples $t$ test was used to compare treatment means of single measurements taken at the end of the experiment. Treatment means for relative growth rate showed unequal variances between droughts and controls, so Satherthwaite adjusted $P$ value was used to report statistical significance. Net assimilation rate was used to determine the efficiency of dry matter accumulation and was calculated by using the equation of Harper (1977): NAR = $\left(\mathrm{W}_{2}-\mathrm{W}_{1}\right) /\left(\mathrm{T}_{2}-\mathrm{T}_{1}\right) \times\left(\log \mathrm{L}_{2}-\log \mathrm{L}_{1}\right) /\left(\mathrm{L}_{2}-\mathrm{L}_{1}\right)$, where $\mathrm{W}$, was the dry weight determined from the initial destructive harvest of three mexican elder trees before irrigation treatments started $\left(\mathrm{T}_{1}\right), \mathrm{W}_{2}$ was the dry weight at day $165\left(\mathrm{~T}_{2}\right)$,

Table 1. Duration of drought cycles, average midday temperature, relative humidity (RH), and photosynthetic photon flux density (PPFD) during five cyclical drought events imposed on mexican elder for $165 \mathrm{~d}$ in 2002. Vapor pressure deficits (VPD) that existed at the time of physiological measurements are included. Plants were allowed a 14-d recovery period between each drought event.

\begin{tabular}{|c|c|c|c|c|c|c|c|}
\hline \multirow[b]{2}{*}{$\begin{array}{l}\text { Drought } \\
\text { no. }\end{array}$} & \multirow[b]{2}{*}{$\begin{array}{l}\text { Start } \\
\text { date }\end{array}$} & \multirow[b]{2}{*}{$\begin{array}{l}\text { End } \\
\text { date }\end{array}$} & \multirow{2}{*}{$\begin{array}{l}\text { Drought } \\
\text { duration } \\
\text { (d) }\end{array}$} & \multicolumn{3}{|c|}{ Midday } & \multirow[b]{2}{*}{$\begin{array}{l}\mathrm{VPD} \\
(\mathrm{kPa})\end{array}$} \\
\hline & & & & $\begin{array}{l}\text { Temp } \\
\left({ }^{\circ} \mathrm{C}\right)\end{array}$ & $\begin{array}{l}\text { RH } \\
(\%)\end{array}$ & $\begin{array}{c}P P F D \\
\left(\mu \mathrm{mol} \cdot \mathrm{m}^{-2} \cdot \mathrm{s}^{-1}\right)\end{array}$ & \\
\hline$\overline{1}$ & 18 Feb. & 17 Mar. & 28 & $14.8(14.0)^{z}$ & $16(13)^{\mathrm{z}}$ & $988(884)^{z}$ & 1.40 \\
\hline 4 & 3 June & 15 June & 12 & $35.5(32.7)$ & $21(21)$ & $1826(1861)$ & 3.93 \\
\hline 5 & 12 July $^{y}$ & 2 Aug. & 22 & $29.4(28.5)$ & $37(43)$ & $936(1460)$ & 2.20 \\
\hline
\end{tabular}

${ }^{2}$ Environmental condition that existed during physiological measurements is in parentheses.

${ }^{y}$ Drought cycle initially started on 29 June 2002, but was aborted due to $2.8 \mathrm{~mm}$ of rain on 4 July 2002. 
Table 2. Least square means and standard deviations $\left( \pm\right.$ ) for significant effects of predawn $\left(\psi_{\text {p }}\right)$ and midday $\left(\psi_{\text {md }}\right)$ stem water potential in control and drought plants of mexican elder subjected to $165 \mathrm{~d}$ of cyclic drought. Probability values from the mixed model analysis are included for each source of variation.

\begin{tabular}{lcccc}
\hline \multirow{2}{*}{ Variable } & \multicolumn{2}{c}{$\psi_{\text {pd }}(-\mathrm{MPa})$} & \multicolumn{2}{c}{$\psi_{\text {md }}(-\mathrm{MPa})$} \\
\cline { 2 - 5 } Drought cycle & Control & Drought & Control & Drought \\
$\quad 3$ & $0.52 \pm 0.17$ & $0.84 \pm 0.13$ & $1.13 \pm 0.15$ & $1.35 \pm 0.10$ \\
4 & $0.47 \pm 0.06$ & $0.61 \pm 0.30$ & $1.12 \pm 0.08$ & $1.26 \pm 0.19$ \\
5 & $0.72 \pm 0.22$ & $0.76 \pm 0.11$ & $1.14 \pm 0.26$ & $1.53 \pm 0.21$ \\
Treatment mean (SE) & $0.57(0.03) \mathrm{a}^{\mathrm{z}}$ & $0.740(0.03) \mathrm{b}$ & $1.13(0.07) \mathrm{a}$ & $1.38(0.07) \mathrm{b}$ \\
Significance $(P$ values $)$ & & & & 0.0344 \\
$\quad$ Treatment & \multicolumn{2}{c}{0.0092} & & 0.0605 \\
$\quad$ Drought cycle & \multicolumn{2}{c}{0.1074} & & 0.1242 \\
$\quad$ Treatment $\times$ drought cycle & \multicolumn{2}{c}{0.3292} & & \\
\hline
\end{tabular}

${ }^{2}$ For either $\psi_{\mathrm{pd}}$ or $\psi_{\mathrm{md}}$, least squares means with the same letter are not significantly different.
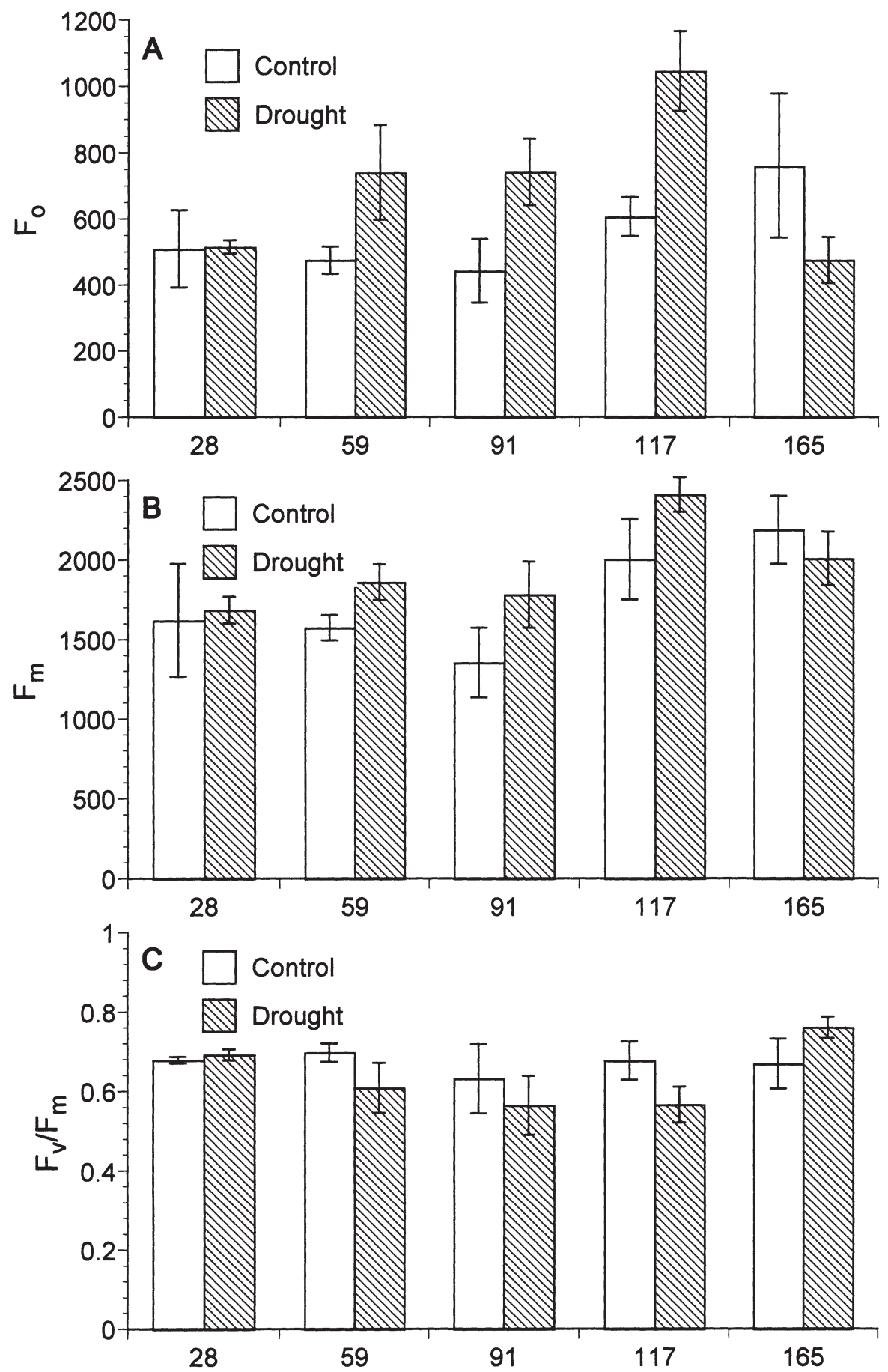

Days after February 18, 2002 and $\mathrm{L}_{2}$ and $\mathrm{L}_{1}$ were the leaf surface area within irrigation treatments at $\mathrm{T}_{2}$ and $\mathrm{T}_{1}$ respectively. Relative growth rate was used to determine irrigation treatment impact on growth and was calculated using an equation modified from Gutschick and Kay (1995): $R G R=\left(\ln W_{2}-\ln \right.$ $\left.\mathrm{W}_{1}\right) /\left(\mathrm{T}_{2}-\mathrm{T}_{1}\right)$, where $\mathrm{W}_{2}$ was the dry weight at day $165\left(\mathrm{~T}_{2}\right)$, within irrigation treatments and $\mathrm{W}_{1}$ was the dry weight determined from the initial destructive harvest $\left(\mathrm{T}_{1}\right)$ before irrigation treatments began.

\section{Results and Discussion}

Plants in the drought treatment completed five drought cycles and the length of a drought cycle varied because of differences in evapotranspiration (Table 1). During the entire experimental period there was only one measurable precipitation (rainfall) event(Table 1). Because of this rainfall, moisture content of the substrate increased by a percent. Plants were allowed to recover (watered daily) for $10 \mathrm{~d}$ before initiating the final drought cycle. Drought-stressed plants had more negative $\psi_{\text {pd }}$ and $\psi_{\text {md }}$ than controls (Table 2). Increased negativity of midday water potential may be the result of severely reduced soil moisture and lower water conduction from roots to leaves (Kramer, 1983; Zwack et al., 1998). Neither drought cycle nor the interaction between treatment and drought cycle was significant for $\psi_{\mathrm{pd}}$ and $\psi_{\mathrm{md}}$, suggesting that differences in stem water potential at each drought cycle were relatively stable.

When photosystem II (PSII) is able to shunt the majority of the light-activated electrons to photosynthesis, thus allowing the PSII reaction centers to be fully open for energy influx, fluorescence is at a minimum $\left(\mathrm{F}_{0}\right)$ (Mir et al., 1998). Treatment $(P=0.0284)$, but not drought cycle $(P=0.1135)$ affected $\mathrm{F}_{0}$. As suggested in Fig. 1A, the quadratic interaction for treatment by drought cycle was significant $(P=0.0036)$, but the linear interaction was not $(P=0.4635)$. Comparison of least squares means (Fig. 1A) indicated that the significant quadratic interaction may be a result of the large mean for the drought group at drought cycle four. A larger mean for $\mathrm{F}_{0}$ could indicate a decreased capacity of PSII to process light energy.

Overall, there were no treatment differences for maximal fluorescence $\left(\mathrm{F}_{\mathrm{m}}\right)(P=0.0892)$, the fluorescence condition that occurs when light intensity is too high for energy to be processed. However, the drought cycle main effect was statistically significant $(P=0.0104)$ (Fig. 1B). At drought cycles four and five, $\mathrm{F}_{\mathrm{m}}$ rates were among the highest (Fig. 1B). An increase in $\mathrm{F}_{\mathrm{m}}$ could indicate a decline in chlorophyll pigment content (Mir et al., 1998).

The ratio of variable to maximal fluorescence $\left(F_{v} / F_{m}\right)$ is a measure of the maximum quantum efficiency of energy capture by

Fig. 1. Chlorophyll fluorescence in control and drought plants of mexican elder during $165 \mathrm{~d}$ of cyclic drought: (A) minimal fluorescence $\left(\mathrm{F}_{\mathrm{o}}\right)$, (B) maximal fluorescence $\left(\mathrm{F}_{\mathrm{m}}\right)$, and the ratio of variable to minimal fluorescence $\left(\mathrm{F}_{\mathrm{v}} / \mathrm{F}_{\mathrm{m}}\right)$. Bars on columns represent standard errors $(\mathrm{n}=5)$. 

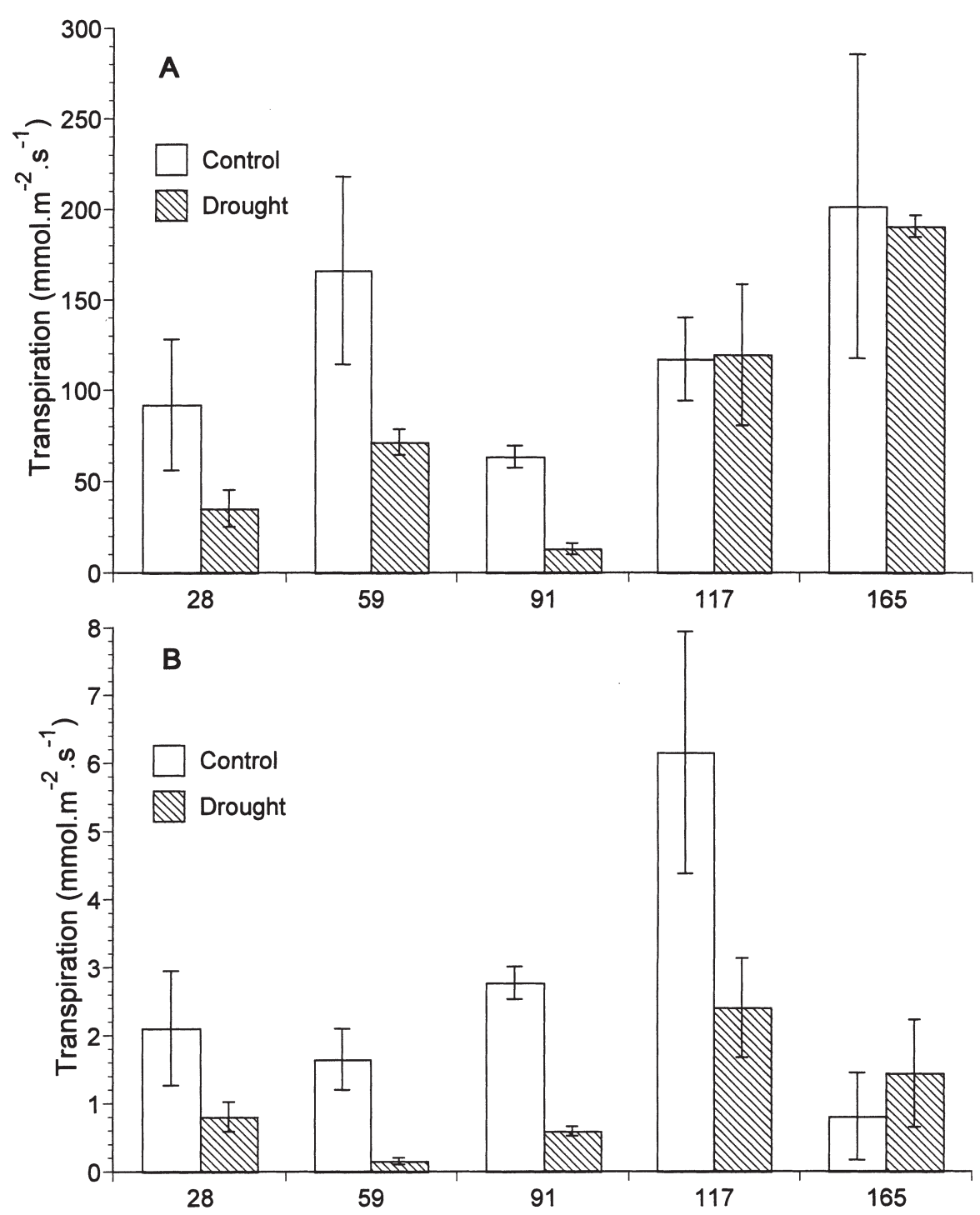

Days after February 18, 2002

Fig. 2. Stomatal conductance (A) and transpiration (B) of mexican elder subjected $165 \mathrm{~d}$ of cyclic drought. Bars on columns represent standard errors $(n=5)$.

Table 3. Relative water content (RWC), net assimilation rate (NAR), and relative growth rate (RGR) of mexican elder plants after 165 d of daily irrigation (control) or cyclic drought treatment. Values are the means of five replications \pm SD.

\begin{tabular}{lccc}
\hline Treatment & $\begin{array}{c}\text { RWC } \\
(\%)\end{array}$ & $\begin{array}{c}\text { NAR } \\
\left(\mathrm{mg} \cdot \mathrm{cm}^{-2} \cdot \mathrm{d}^{-1}\right)\end{array}$ & $\begin{array}{c}\mathrm{RGR} \\
\left(\mathrm{mg} \cdot \mathrm{g}^{-1} \cdot \mathrm{d}^{-1}\right)\end{array}$ \\
\hline Control & $76 \pm 7$ & $0.3 \pm 0.1$ & $5.5 \pm 1.4$ \\
Drought & $66 \pm 6$ & $0.5 \pm 0.4$ & $5.3 \pm 3.0$ \\
$P$ value & 0.0444 & 0.3185 & 0.8756 \\
\hline
\end{tabular}

open centers in PSII (Bauerle et al., 2003) and can provide evidence of chloroplast activity. In healthy tissues, the ratio of variable to maximal fluorescence $\left(\mathrm{F}_{\mathrm{v}} / \mathrm{F}_{\mathrm{m}}\right)$ is generally at or approaching 0.8 (Mir et al., 1998). At the end of drought cycle five, $\mathrm{F}_{\mathrm{v}} / \mathrm{F}_{\mathrm{m}}$ for the drought group averaged 0.76 (Fig. 1C), suggesting that the drought group maintained photosynthesis near optimal levels. Neither treatment $(P=0.3399)$ nor drought cycle $(P=0.2428)$ affected $\mathrm{F}_{\mathrm{v}} / \mathrm{F}_{\mathrm{m}}$. Chlorophyll fluorescence is usually affected only after exposure to severe whole-plant conductivity to water (Brodribb and Hill, 2000) may reduce transpiration rates. While this might be true for mexican elder, further study is needed to determine how episodic drought affects the mechanisms of whole plant water conductivity of mexican elder.

Cell osmotic potential averaged $-1.73 \mathrm{MPa}$ in drought-stressed plants and $-1.54 \mathrm{MPa}$ in well-watered plants but there was no statistical difference between treatments $(P=0.3776)$. Cell osmotic potential of the drought plants varied for the five drought cycles, but was just short of our defined probability level $(P=0.05)$ only within drought cycles $(P=0.0569)$.

Because water was not a limiting factor for control plants, the higher relative water content of those plants (76\%) compared to the drought group $(66 \%)$ was anticipated (Table 3$)$. Reduction of photosynthetic activity generally occurs when relative water content is between $40 \%$ and $70 \%$, a possible result of increased cell solutes inhibiting enzyme activity in the chloroplasts (Chaves, 1991). Relative water content of drought-stressed plants was within the range specified for reduced photosynthetic activity. However, NAR and RGR values(Table 3 ) suggest that plants in both irrigation treatments accumulated biomass at the same rate and had similar efficiencies in assimilating that biomass (Balok and St. Hilaire, 2002).

Leaf DW of drought-stressed plants was three times lower than that of well-irrigated plants (Table 4). Control plants received six more fertilizer applications than droughtstressed plants. Thus, the plant nutrient status could impact our results. Shoot and root DW were statistically similar between irrigation treatments. In drought-stressed plants, root DW formed $96.1 \%$ of the total plant biomass compared to $0.2 \%$ and $3.7 \%$ for leaves and shoots, respectively (Table 4 ). While the maintenance of a large root mass would allow drought-stressed mexican elder plants to recover rapidly from drought when moisture becomes available, there were no treatment differences $(P=0.2971)$ in the ratio of root to shoot biomass. Plants exposed to drought had a lower leaf DW to root DW ratio than well-watered plants (Table 4).

We observed leaf drop in both control and drought-stressed plants. However, after the final destructive harvest, total leaf area of the controls was over four times higher than that of plants exposed to drought (Table 4). Because there were no differences in specific leaf weight, our data on leaf area and leaf DW suggest that drought-stressed plants had either fewer or smaller leaves or both. We observed both fewer and smaller leaves. These findings are consistent with the empirical observations of plants growing in managed landscapes. The reduction in transpirational surface area is an important drought-response mechanism in many plants. The reduced leaf area of drought-stressed plants might compromise the landscape appeal of mexican elder and lead landscape personnel to conclude that the plant performs poorly in arid regions of the Southwest. Although this strategy will enhance the potential of mexican elders to survive long-term drought that is common to 
Table 4. Leaf, shoot and root dry weight (DW), biomass allocation patterns, leaf area, and specific leaf weight (SLW) of mexican elders after $165 \mathrm{~d}$ of daily irrigation (control) or cyclic drought treatments. Values are the means of five replications \pm SD.

\begin{tabular}{|c|c|c|c|c|c|c|}
\hline Treatment & Leaf DW $(\mathrm{g})$ & Shoot DW (g) & Root DW (g) & Leaf DW/root DW & Leaf area $\left(\mathrm{cm}^{2}\right)$ & SLW $\left(\mathrm{mg} \cdot \mathrm{cm}^{-2}\right)$ \\
\hline Control & $26.2 \pm 3.75$ & $233 \pm 217$ & $3584 \pm 967$ & $0.0087 \pm 0.0027$ & $1307 \pm 269$ & $20.4 \pm 3.2$ \\
\hline$P$ value & $<0.0001$ & 0.5267 & 0.8273 & 0.0021 & 0.0001 & 0.1565 \\
\hline
\end{tabular}

the Southwest, reduced leaf area will severely limit the ornamental value of these plants.

\section{Literature Cited}

Adrian, J.L., C.C. Montgomerry, B.K. Behe, P.A. Duffy, and K.M. Tilt. 1998. Cost comparisons for infield, above ground container and potin-pot production systems. J. Environ. Hort. 16:65-68.

Balok, C.A. and R. St. Hilaire. 2002. Drought responses among seven southwestern landscape tree taxa. J. Amer. Soc. Hort. Sci. 127: 211-218.

Bauerle, W.L., J.B. Dudley, and L.W. Grimes. 2003. Genotypic variability in photosynthesis, water use, and light absorption among red and Freeman maple cultivars in response to drought stress. J. Amer. Soc. Hort. Sci. 128:337-342.

Baz, M. and R.T. Fernandez. 2002. Evaluating woody ornamentals for use in herbicide phytoremediation. J. Amer. Soc. Hort. Sci. 127:991-997.

Brodribb, T.J. and R.S. Hill. 2000. Increases in water potential gradient reduce xylem conduc- tivity in whole plants. Evidence from a lowpressure conductivity method. Plant Physiol. 123:1021-1028

Chaves, M.M. 1991. Effects of water deficits on carbon assimilation. J. Expt. Bot. 42:1-16.

Devitt, D.G., J.R. Simpson, and J.L. Tipton. 1995. Water use of two landscape tree species in Tucson, Arizona. J. Amer. Soc. Hort. Sci. 120:409-416.

Feser, C. 2003. Plant water relations, evapotranspiration, and development traits of mexican elder plants subjected to various irrigation regimes. MS thesis. N.M. State Univ., Las Cruces.

Gutschick, V.P. and L.E. Kay. 1995. Nutrient-limited growth rates: quantitative benefits of stress responses and some aspects of regulation. J. Expt. Bot. 46:995-1009.

Handreck, K. and N. Black. 2002. Growing media for ornamental plants and turf. 3rd ed. Univ. New S. Wales Press, Sydney, Austral.

Harper, J.L. 1977. Population biology of plants. Academic, London.

Kramer, P.J. 1983. Water relations of plants, p. 174-311. Academic Press, New York.
Martin, C.A., L.B. McDowell, and S. Bhattacharya 1999. Below ground pot-in-pot effects on growth of two southwest landscape trees was related to root membrane thermostability. J. Environ. Hort. 17:63-68.

Mir, N., M.Wendorf, R. Perez, and R.M. Beaudry. 1998. Chlorophyll fluorescence in relation to superficial scald development in apple. J. Amer. Soc. Hort. Sci. 123:887-892.

Ruter, J.M. 1998. Fertilizer rate and pot-in-pot production increases growth of Heritage River Birch. J. Environ. Hort. 16:135-138.

St. Hilaire, R., C.F. Feser, T.W. Sammis, and A.S. St. Hilaire. 2003. A system to measure evapotranspiration of in-ground container plants of mexican elder. HortTechnology 13:185-189.

Young, R.E. and G.R. Bachman. 1996. Temperature distribution in large, pot-in-pot nursery containers. J. Environ. Hort. 14:170-176.

Zwack, J.A., W.R. Graves, and A.M. Townsend. 1998. Leaf water relations and plant development of three freeman maple cultivars subjected to drought. J. Amer. Soc. Hort. Sci. $123: 371-375$ 